\title{
Representing Islam in Indonesian Film Advertising during the Suharto Era (1966-1998) and Reform Era (1998-Present)
}

\author{
Christopher A. Woodrich ${ }^{1, a)}$ \\ ${ }^{1}$ International Indonesia Forum/Gadjah Mada University, chris_woodrich@hotmail.com

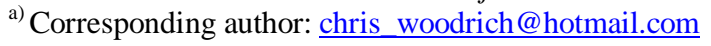

DOI:https://doi.org/10.18196/jkm.101006

Article Info

Article history:

Received 12 Agst

2018

Revised 20 Sept 2018

Accepted 19 Okt 2018

\section{ABSTRACT}

This article examines how Islam has been depicted in advertisements for Indonesian films over the past fifty years. It finds that, during the Suharto Era (1966-1998), Islam was generally not represented explicitly in film advertisements; however, examples could still be found in advertisements for films intended to preach Islamic values as well as in advertisements for films with more general themes. The use of Islamic symbols became more common during the Reform Era (1998-present), particularly following the rise of the film Islamic genre. Advertisements in both eras used such symbols as turbans, skullcaps, and headscarves, as well as other common symbols of Islam. However, advertisements differed in two key aspects. First, where advertisements in the Suharto era tended to embrace viewers of all backgrounds, advertisements in the Reform era have often positioned Islam as more exclusive. Second, where advertisements in the Suharto era tended to illustrate a dynamicity in discourses on Islamic identity, advertisements in the Reform era have generally promoted a more singular understanding of Indonesian Islamic identity.

Keywords: film advertising, Indonesian cinema, Islam in Indonesia

\begin{abstract}
ABSTRAK
Dalam artikel ini, representasi agama Islam dalam iklan film Indonesia selama 50 tahun dilacak. Ditemukan bahwa, pada masa Suharto (1966-1998), agama Islam cenderung tidak digambarkan dalam iklan film; namun, representasi agama Islam masih ditemukan dalam beberapa iklan, baik yang mengiklankan film dakwah maupun yang mengiklankan film popular. Representasi simbolik dari agama Islam menjadi lebih umum pada masa Reformasi (1998-sekarang), terutama setelah munculnya genre film yang disebut film Islami. Iklan-iklan yang merepresentasikan agama Islam, baik pada masa Suharto maupun masa Reformasi, menggunakan symbol-simbol seperti sorban, peci, dan jilbab, serta beberapa simbol lain. Namun, ada dua perbedaan yang sangat penting. Pertama, walau iklan film pada masa Suharto cenderung merangkul penonton dari semua latar belakang, iklan film pada masa Reformasi cenderung menggambarkan agama Islam sebagai sesuatu yang lebih eksklusif. Kedua, walau iklan film pada masa Suharto cenderung merepresentasikan agama Islam sebagai sesuatu yang dinamis dan beragama, iklan film pada masa Reformasi cenderung menggambarkan agama Islam di Indonesia sebagai sesuatu yang tunggal.
\end{abstract}

Kata kunci: periklanan film, sinema Indonesia, Islam di Indonesia

\section{INTRODUCTION}

Indonesia, as led by President Suharto, was identified as a 'unitary state in the form of a republic', based in the religious (but non-sectarian) national philosophy known as Pancasila. This was identified variously by foreign observers as an attempt to create a secular nation (Crossette, 1985) or a 
regime with secular leanings (Vatikiotis, 1998). As Indonesia implemented capitalist development policies friendly to Western investors through the 1970s (Ricklefs, 2008), it enacted several policies that were considered to limit the public practice of religion, including Islam-the majority religion. For instance, the government prohibited the wearing of headscarves at State-operated schools in 1982 (van Wichelen, 2009), and banned all organizations that refused to recognize Pancasila as their sole ideological basis, including Islamic ones (Ramage, 1995). Islamic political parties, numerous in the previous regime, were consolidated into a single party called the Partai Persatuan Pembangunan (United Development Party). Through the 1970s and 1980s, the government detained hundreds of Muslim activists, and even used military force against Muslim protestors, ${ }^{1}$ in an attempt to mitigate the influence of political Islam (Ricklefs, 2008).

At the same time, however, Islam's practice and cultural influence grew extensively. Government limits on public political participation led to Islamic-oriented activities and spaces becoming 'some of the best opportunities for open discussion of public issues' (Hefner, 1999, p. 43), while national religious education curricula reduced syncretism. Suharto, shortly after undertaking a minor pilgrimage (umroh) to Mecca in 1977, began subsidizing mosque construction (Ricklefs, 2008). Works with Islamic themes were also produced semi-regularly. Ahmad Tohari's novel Kubah (Dome, 1980), for instance, offered the religion as a means of finding unity, oneness, and internal peace (Woodrich, 2015), while authors such Emha Ainun Nadjib, Kuntowijoyo, and Mustofa W. Hasyim drew on various Islamic themes in their works (Salam, 2004). Films, meanwhile, dealt with topics such as the hajj pilgrimage (Panggilan Ka'bah [Call of the Kaaba, 1977]), religious education (Al Kautsar [The Blessing, 1977]), and religion's role in Indonesian independence (Sunan Kalijaga [1983]).

By the late 1980s, such tendencies had compounded to establish an Islamic revival, and over time laws limiting Islamic practice_-such as the ban on wearing headscarves at State schools_-were lifted. Other laws emphasizing Islamic practice, such as the implementation of a religious court system, were passed. In 1991, President Suharto undertook a much-publicized hajj pilgrimage, thereby explicitly and empathetically embracing the 'emotive and familiar message of Islam' (Hasan, 2011). In this environment, diverse Islamic political practices again became possible, and in 1998 - the same year Suharto resigned and Reform began-several new Islamic parties were established. ${ }^{2}$ Through the 2000s, the influence of Islam in Indonesian (Muslim) identity became increasingly concrete, as public displays of piety — such as wearing the headscarf_-became nearly ubiquitous. During this time, Islam also became a dominant theme in Indonesian popular fiction, with works such as Habiburrahman El Shirazy's Ayat-Ayat Cinta (Verses of Love, 2004) selling hundreds of thousands of copies, and new genre of film Islami ${ }^{3}$ emerging from that novel's successful adaptation.

Building on a previous study (Woodrich, 2017), which mapped the representation of Islam in Indonesian film flyers issued during the Suharto era, this article seeks to compare how Islam is represented in Suharto-era and Reform-era film advertisements. This study draws on a corpus of 400 flyers for films produced and released in Indonesia between 1966 and 1998, as well as 200 posters for Indonesian films completed in the 2000s and 2010s. The advertisements examined are not only for films considered Islamic, such as film dakwah (proselytization films) or film Islami (defined above), but also include horror, action, romance, drama, and comedy films. Designed by a wide range of mostly uncredited individuals, these flyers and posters represent some of Indonesian cinema's most productive years (Kristanto, 2007).

This study identifies and describes explicit markers of Islam, defined as visual and linguistic symbols that refer solely or primarily to Islam and Islamic practice, in film advertisements. These markers are then analyzed using a visual semiotics approach, which is intended to identify and map particular trends in the representations of Islam in film advertisements. After completing this mapping, this article uses a comparative approach to identify shifts in the representation of Islam. It

\footnotetext{
See, for example, the Tanjung Priok incident of 1984

Those that remain active as of writing (2018) are the Partai Amanat Nasional (National Mandate Party) Partai Bulan Bintang (Crescent Star Party, PBB), and Partai Kebangkitan Bangsa (National Awakening Party).

Imanda (2012, pp. 90-91) describes such films as follows:

... their religious character has been stressed in promotional tools such as posters and trailers. Their titles usually stem from religious terminology to further emphasize their religious subject matter. Posters of these films show the characters wearing religious attire and posing as in prayer or the like, and trailers also play on the religious character of those movies. In their mise-en-scène, the films also emphasize their religious subject matter: some of the characters consistently wear religious costumes and the actors act according to religious protocols. In some cases, these films even begin or end (or both) with well-known clerics preaching.
} 
concludes by explicating the implications of these shifting trends in representing Islam, and offers recommendations for further research.

\section{DISCUSSION}

\section{Indonesian film advertisements during the Suharto era (1966-1998)}

Page 62 The vast majority of the Suharto-era advertisements surveyed feature no explicit symbols of religious practice, be they Islamic or otherwise. Many depict Indonesians in Western clothing, from jeans (i.e. Anak-Anak Buangan [Youths on the Margin, 1979]) to bikinis (i.e. Permainan Tabu [Taboo Game, 1984]), or participating in activities such as breakdancing (Gejolak Kawula Muda). Others, particularly films based on legends or history, depict traditionally garbed persons outside of a specific religious context. An advertisement for Kutukan Nyai Roro Kidul (The Curse of the Queen of the South, 1979), for instance, depicts the titular character in a green kebaya, while an advertisement for Usia 18 (Age 18,1980) shows a young woman in a simple white kebaya and skirt running through an urban area.

However, in a limited set of flyers, film advertisements released during the Suharto era used a variety of markers to represent Islam. Fashion markers are common. To convey their identity as Muslims, men are depicted as wearing turbans (both sorban and blangkon) or skullcaps (both kopiah and peci $^{4}$ ), and often as having facial hair such as moustaches or beards. Although some examples of an Arabic Muslim identity can be found, such as in Aladin dan Lampu Wasiat (Aladdin and the Magic Lamp, 1980), for the most part these men are readily identifiable as Indonesian. Several, such as the central holy men of Sunan Kalijaga (1983) and Sunan Kalijaga dan Syech Siti Jenar (Sunan Kalijaga and Syech Siti Jenar, 1985), can be identified as Indonesian by their names, while others are identifiable as Indonesian based on their use of the kopiah or peci or their settings.

These men are depicted as being in the midst of various activities. They may be involved in prayer (as in Cinta Segitiga [Love Triangle, 1979]), in sounding the adzan (as in Al-Kautsar [The Abundance, 1977]), in performing remembrances (as in Telaga Angker [Haunted Lake, 1984]), or in a revolutionary struggle (as in Pasukan Berani Mati [Soldiers Willing to Die, 1982]). This range of activities indicates a certain understanding of Muslim masculinity, with a sense of machismo being conveyed. Although a Muslim man is certainly pious, he is also capable of physical confrontation where need be, or even-as implied through collocation in the advertisement for Telaga Angkerdefeating the supernatural. He is thus the imam, the leader, something presented explicitly in Cinta Segitiga, which depicts the doctrinally accepted (Hasyim, 2006) scene of a Muslim man as leading a woman in prayers.

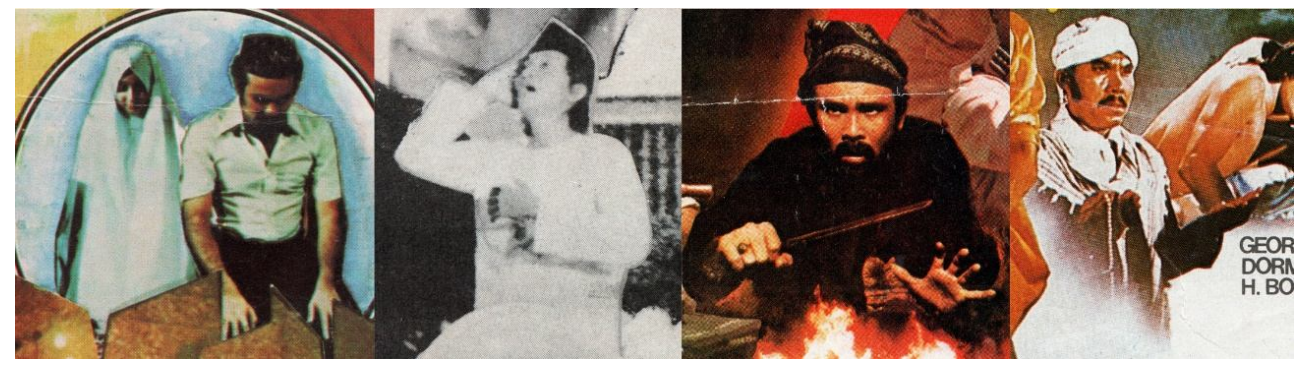

Figure 1. Men wearing turbans and skullcaps in flyers for (L-R): Cinta Segitiga (1979), Al-Kautsar (1977), Pasukan Berani Mati (1982), and Telaga Angker (1984). Note the various activities in which they are involved.

Likewise, women are depicted with specific fashion markers-frequently a form of headscarf-in multiple advertisements. Be they the closed jilbab or open kerudung, headscarves are found in all advertisements for films that classify themselves as dakwah and feature women. ${ }^{5}$ Several

4 For the purposes of this article, kopiah refers to the short, flat-topped, normally black head covering often worn during prayers. Peci, meanwhile, refers to the taller version of this head covering.

Advertisements for the films Sunan Kalijaga (1983) and Sunan Kalijaga dan Syech Siti Jenar (1985) do not give special positioning to any women. However, women in headscarves can be seen in a crowd on the obverse of advertisements for the latter film. 
Vol. 10 No. 2

November 2018

advertisements for films not identified as dakwah also depict women in headscarves. Two of theseBegadang (Vigil, 1978) and Cinta Segitiga (Love Triangle, 1979)—feature the dangdut singer Rhoma Irama, who was also a prominent contemporary $d a^{\prime} i$ and promoter of Islamic teachings. The headscarves worn by women in these advertisements are diverse (Figure 2), including those for prayer (mukena), as in Begadang (1978); headscarves that cover all hair, as in Al Kautsar (1977), headscarves hanging loosely, as in Panggilan Ka'bah (1977); and headscarves that cover only part of the head, as in Para Perintis Kemerdekaan (Pioneers of Freedom, 1977).

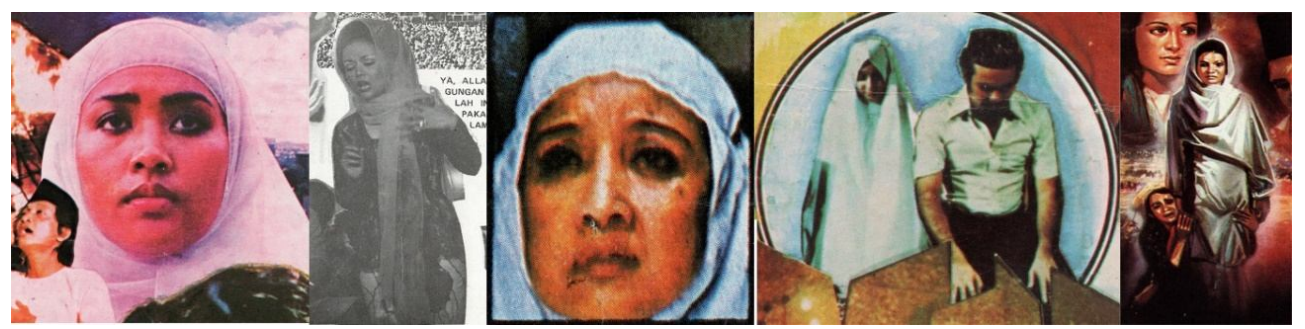

Page $\mid 63$

Figure 2. Women wearing headscarves in flyers for (L-R) Al-Kautsar (1977), Panggilan Ka'bah (1977), Begadang (1978), Cinta Segitiga (1979) and Para Perintis Kemerdekaan (1977).

As with the fashion markers used by men, the fashion markers used by women in these advertisements also invoke contemporary gender constructs. In these flyers, depictions of women wearing headscarves often invoke the act of prayer; meanwhile, where women are shown bearing arms or are otherwise implied to be involved in physical conflict (i.e. three female warriors of Pasukan Berani Mati), they are bereft of religious markers. The only woman in the advertisements surveyed who is shown to be both wearing a veil and resisting some (unseen) force-in Para Perintis Kemerdekaan - is not depicted as fighting aggressively, but as resisting an unspecified outside force. Women wearing headscarves in these advertisements, thus, seem to embody the ideal of women as maintainers of tradition, as moral guardians (Brenner, 1999), but also-as in the advertisement for Cinta Segitiga - as followers of men.

Prominent in several advertisements, primarily those positioned as film dakwah, are linguistic markers. Several of the flyers surveyed use Arabic script, be it the original script complete with diacritics or the adapted Malay script known as Jawi. In Sunan Kalijaga dan Syech Siti Jenar, this script is used for the title of the film being advertised, providing a supplement to the Latin-script title also provided. An advertisement for Sunan Kalijaga, meanwhile, uses Arabic script to present the film's title as well as two religious invocations in the Indonesian language (Figure 3), respectively calling readers to bring themselves closer to God, use Him as a guide for their temporary life on earth, and donate money to charity; and reminding readers that providing charity and supporting the poor are obligations for all Muslims.

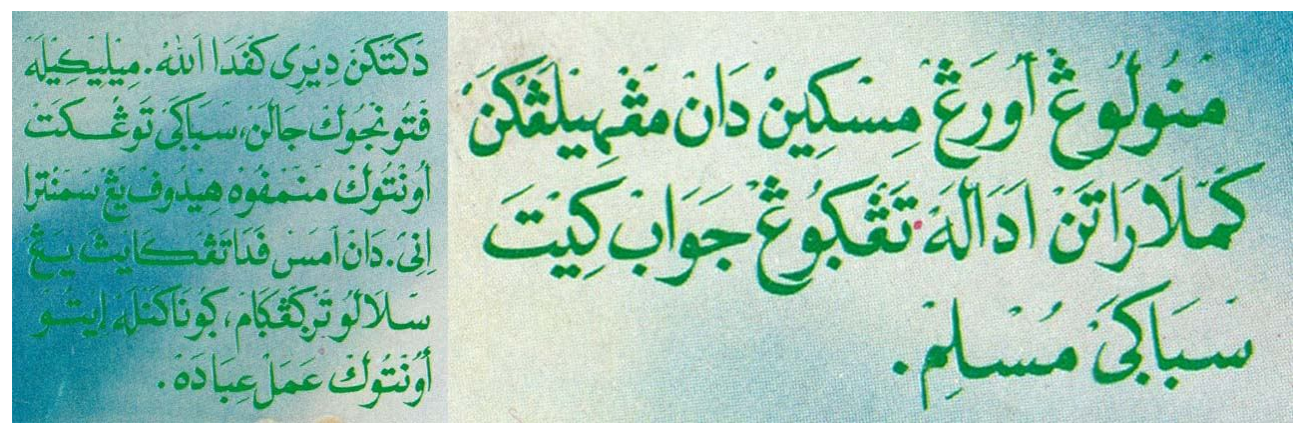

Figure 3. Religious invocations on the flyer for Sunan Kalijaga (1983)

This extends also to use of the Arabic language, be it in Arabic script or in Latin script. The former is relatively uncommon. Of the flyers surveyed, only advertisements for Al-Kautsar use this approach; one includes the takbir الهبر (God is Great), while another contains the entire Qur'anic 
chapter Al-Kautsar. Romanized versions of Arabic are more common. In advertisements for $A l$ Kautsar, this includes the film's title, Al-Kautsar, which refers to the $108^{\text {th }}$ sura of the Qur'an, as well as phrases such as assalamu'alaikum warhomatullohi wabarokatu ('May the peace, mercy, and blessings of God be with you') and Alhamdulillah ('Praise be to God!'). Other film advertisements use the Arabic loanword hajji in referring to their casts (as in Panggilan Ka'bah) or their characters (as in Para Perintis Kemerdekaan).

Page |64 Also representing Islam in these advertisements are specific practices and artifacts. Three advertisements, for example, use the Qur'an and practices involving to indicate that a film is intended to function as dakwah. This holy book may be shown radiating light, as in one advertisement for $A l$ Kautsar; linked to excerpts through collocation, as in another advertisement for Al-Kautsar; or simply shown as being read, as in an advertisement for Sunan Kalijaga dan Syech Siti Jenar. Also shown in several advertisements are prayer beads (tasbih) and the utterance of remembrances (zikir). These take a central position in an advertisement for Sunan Kalijaga, where the central figure holds a string of prayer beads in his right hand as he gazes towards the heavens; they are also held by the kyai in the advertisement for Telaga Angker.

Indeed, the reciting of the Qur'an and other forms of worship are frequently depicted in advertisements. These may take various forms, including a call to prayer (adzan), as in Cinta Segitiga; an act of supplication, as in Cinta Segitiga; or even standing with palms facing upwards, as in Panggilan Ka'bah. Another form of worship, the hajj pilgrimage, is central to the flyers for films such as Panggilan Ka'bah and Ya Allah Ampuni Dosaku (Oh God, Absolve Me of My Sins, 1978); this is not surprising, as both films have the hajj pilgrimage as a central element (Kristanto, 2007). These advertisements both depict an enormous group, numbering in the thousands, circumambulating the Kaaba (i.e. conducting the tawaf, part of the pilgrimage in which Muslims walk around the Kaaba seven times).

In advertisements featuring the hajj pilgrimage, the Masjid Al-Haram and Kaaba are shown. Other famous mosques, as well as silhouettes of mosques, can also be seen in other advertisements (Figure 4). For example, advertisements for Al-Kautsar feature the Istiqlal Mosque, the largest mosque in South-East Asia, which was approaching completion at the time of the film's production (Melton, 2014). The advertisement for Sunan Kalijaga, meanwhile, depicts the Great Mosque of Demak, one of Java's oldest mosques, the construction of which is widely attributed to Sunan Kalijaga (Intan, 2006). Silhouettes of mosques, featuring the onion-shaped domes and minarets that characterize Arabic-style mosques, are also found in advertisements for Al-Kautsar and Cinta Segitiga.

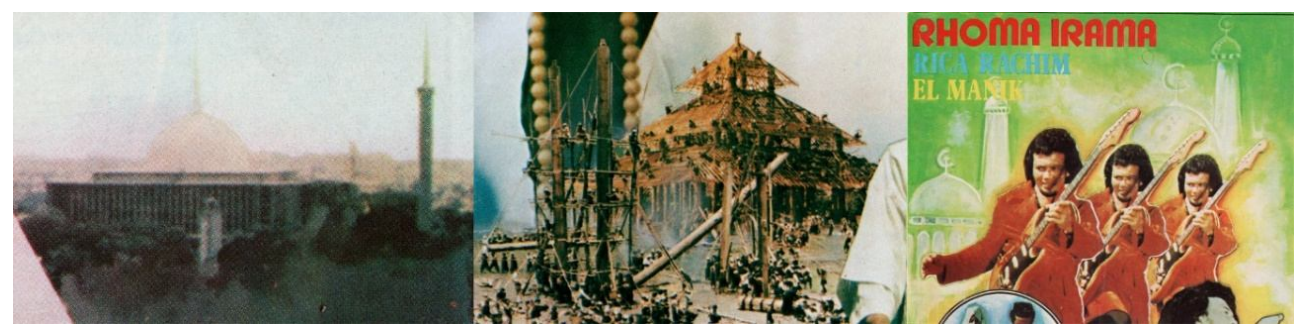

Figure 4. Depictions of the Istiqlal Mosque (Al-Kautsar, 1977), Great Mosque of Demak (Sunan Kalijaga, 1983), and a silhouette of a mosque (Cinta Segitiga, 1979)

Two key oppositions in these advertisements are of particular pertinence to the discussion here: unity and diversity, and non-exclusivity and special positioning. Pursuant to the understanding of the Muslim religious community as a single ummah, united in faith despite different social, cultural, and political backgrounds (Saeed, 2015), the film advertisements surveyed rarely depict persons marked with an explicitly Islamic identity as committing violence against other persons marked with an explicitly Islamic identity. Except for one interaction, ${ }^{6}$ interactions between Muslims are depicted as positive, involving prayer (Panggilan Ka'bah), mosque construction (Sunan Kalijaga), sermons (Sunan Kalijaga dan Syech Siti Jenar), etc.

In an advertisement for Sunan Kalijaga dan Syech Siti Djenar, a man in a turban is depicted as being beheaded as other men in turbans look on. This is implied to be a righteous execution, as the person in question is kneeling, his hands seemingly bound, as a criminal. 
Vol. 10 No. 2

November 2018

This unity is most clearly marked in the advertisement for Panggilan Ka'bah, where all wear the same clothing (white ihram) and conduct the same practice (circumambulating the Kaaba). Individual backgrounds are lost in a sea of Muslim unity and equality (Figure 5).

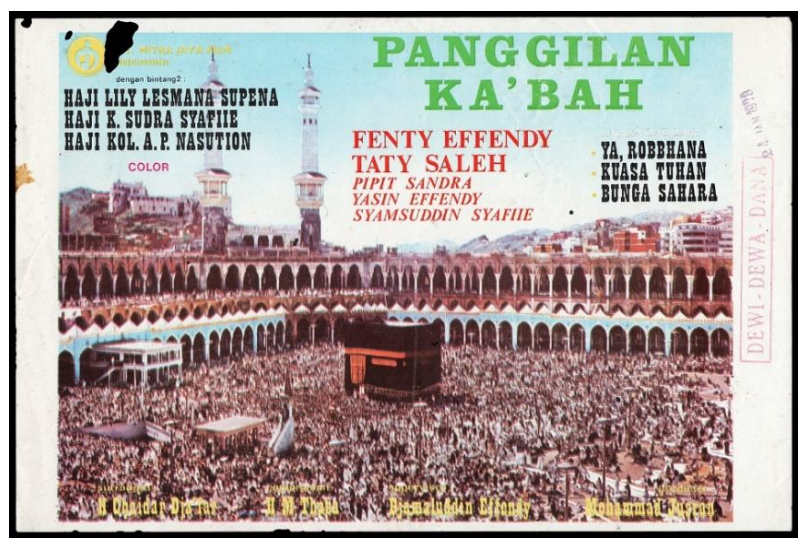

Page $\mid 65$

Figure 5. Panggilan Ka'bah (1977)

Nonetheless, individual practices of Islam are shown as being diverse. As noted above, men and women are shown wearing various forms of head coverings (Figure 6), reflecting a range of sociocultural traditions-sometimes in the same advertisement. None of these fashion markers is given priority over others, suggesting an equal positioning. Similar diversity is evident in other depicted religious artifacts and practices, including mosques and worship. As implied above, markers of Islam in these advertisements show affiliation towards both Arabicized and traditional Indonesian cultural practices of Islam, what has become known as Islam Nusantara. Neither affiliation is given priority, and indeed the two may be complementary; in one flyer for Al-Kautsar, for example, Arabicized mosque architecture exists side by side with headscarves in the kerudung style and skullcaps.

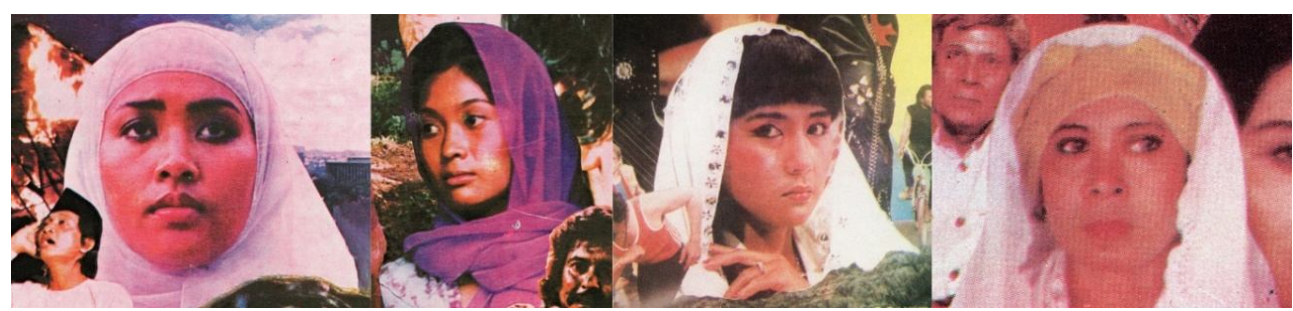

Figure 6. Various styles of headscarf in Al-Kautsar (1977), Al-Kautsar (1977), Menggapai Matahari II (1986), and Si Pitung Beraksi Kembali (1981).

Second, there is an interesting contrast between non-exclusivity and special positioning of Islam. In the film advertisements surveyed, the Islamic identity presented was not exclusive. Characters are shown as having multi-faceted identities, of which Islam was but a part. Muslim figures embody an Indonesian nationalist identity in several flyers, such as Para Perintis Kemerdekaan and Pasukan Berani Mati, while in others, such as Si Pitung Beraksi Kembali [Si Pitung Strikes Again, 1981] and Satria Bergitar (Knight with a Guitar, 1983), they embody resistance to oppressive forces. In the latter, this warrior is also carrying a guitar, implying musical activities. In these advertisements, being Muslim does not mean looking only towards the heavens, but also facing life on Earth.

Likewise, Islam is not given an exclusive position in Indonesian religious discourse. Advertisements for films explicitly intended as dakwah, for example, seek also to draw non-Muslim audiences. One advertisement for Sunan Kalijaga dan Syech Siti Jenar, for example, offered ten national savings accounts equivalent to the cost of going on the hajj pilgrimage as grand prizes, rather than the hajj pilgrimage itself, which could not be enjoyed by non-Muslims. Meanwhile, advertisements for Al-Kautsar and Sunan Kalijaga contain quotations that are explicitly identified as 
coming from a Christian viewer. In an advertisement for Al-Kautsar, the film director Teguh Karya is quoted as saying, 'I'm a Christian, but I'm very proud to see this film. It's very good and not exclusively for Muslims, but for all religious persons.' Meanwhile, regarding Sunan Kalijaga, Sutadi-a reporter with the Padang-based daily Haluan - is quoted thusly: 'It is not only Muslims who should see this film, keeping in mind the contents of its mission and theme. I'm a Christian, but I was touched to see this film.'

Page 66 However, even given this non-exclusivity, advertisements depicting markers of Islam are more common in the corpus than flyers depicting markers of other religions. Of the Suharto-era advertisements surveyed, only one religion other than Islam was depicted explicitly: Christianity. Some advertisements featured churches, such as Karmila (1974); Catholic nuns, such as Permainan Bulan Desember (A December's Game, 1980); or crosses, such as Jakarta, Jakarta (1977), shows a cross and a woman in a Western-style wedding dress. Unlike advertisements depicting markers of Islam, advertisements depicting Christianity did not include text affirming Christianity or contain commentary regarding universal lessons. Rather, these advertisements used approaches similar to advertisements for films without explicit markers of religion. Only in dakwah films is the role of religion advertised, indicating Islam's special position in contemporary Indonesian discourse.

\section{Indonesian film advertisements during the Reform era (1966-1998)}

Following the fall of Suharto in 1998, and as a consequence of decades of Islamic revival, film advertisements in Indonesia began to include markers of Islamic religious identity more regularly. However, such film advertisements existed together with advertisements that featured not explicit symbols of religious practice. As in the Suharto Era (albeit with less revealing styles), many advertisements depict Indonesians wearing Western clothing, running the gamut from V-necked shirts (i.e. Brownies [2004]) to band T-shirts (Galih dan Ratna [Galih and Ratna, 2016]). Many depict Indonesians in explicitly foreign contexts, such as the tulip fields of the Netherlands (Negeri van Oranje, 2015) or the canals of Venice ( $L D R, 2015)$. Films based on legends or history, meanwhile, have continued to depict traditionally garbed persons outside of a specific religious contexts, as in Kartini (2017).

As with the Suharto era, films advertisements in the Reform era that include markers of Islam have utilized a broad variety. As previously, fashion markers have been common. Men in these advertisements continue to wear turbans or skullcaps, and may be presented with facial hair such as moustaches or beards. However, turbans are uncommon in advertisements for films set in contemporary Indonesia; examples identified in this study (Figure 7) are taken from posters for Sang Pencerah (The Lightbringer, 2013) and Sang Kiai (The Scholar, 2015), both films with historical settings. Rather, where head coverings are worn by men, be they children (as in the poster for Negeri di Bawah Kabut [Land under the Fog, 2011]) or adults (as in the poster for Dalam Mihrab Cinta [In the Prayer Niche of Love, 2011). Men may also be depicted as wearing baju koko, a Chineseinfluenced garment identified as Islamic in contemporary discourse.
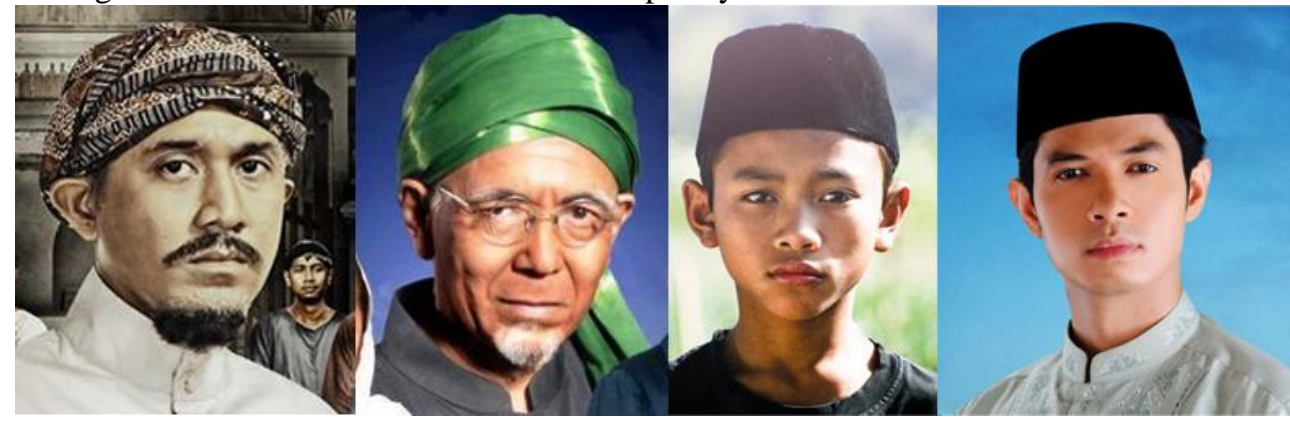

Figure 7. Depictions of men in Muslim garb in Sang Pencerah (2010), Sang Kiai (2013), Negeri di Bawah Kabut (2011), and Dalam Mihrab Cinta (2011).

These men, however, are rarely depicted as being in the midst of certain activities. ${ }^{7}$ Rather, they are generally shown as part of a group, standing still, facing the viewer, part of a group of people that

\footnotetext{
The poster for Mencari Hilal, discussed below, is one exception.
} 
Vol. 10 No. 2

November 2018

are standing together. Where these men are younger (and thus appealing to young adults, who make up the majority of movie-goers in Indonesia [citation needed]), they are generally positioned at the forefront of the group; where these men are older, they are more commonly positioned at the back of the group, as in the poster for Ketika Cinta Bertasbih (When Love Prays, 2009). This forefronting of individuals, and simultaneous lack of emphasis on action, suggests that these advertisements' understandings of Muslim masculinity are not derived from activities, but rather presentation. In these film advertisements, Muslim men are well-groomed and well-dressed, and while they may be smoothfaced in their youths, as they mature they will grow and maintain beards. Theirs is not the active and macho masculinity of the Suharto era, but an urbane one.

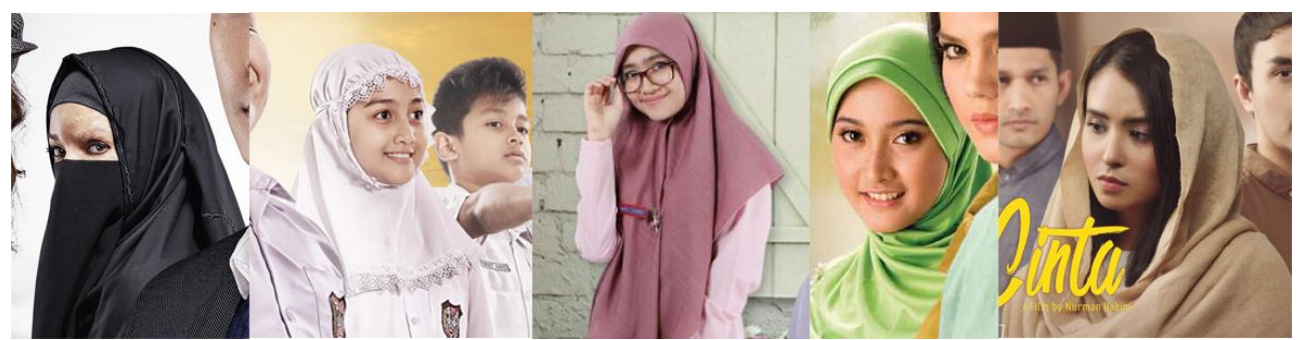

Figure 8. Depictions of women in veils in Ayat-Ayat Cinta 2 (2017), Surau dan Silek (2017), Cahaya Cinta Pesantren (2017), Ketika Cinta Bertasbih (2009), and Bid'ah Cinta (2017)

Representations of women wearing veils in Indonesian film advertisements, meanwhile, have become increasingly common, such that it has become codified-in films with Islamic themes-as representing an 'authentic feminine Muslimhood', an 'almost mandatory visual code in the twenty-first century' (Lücking \& Eliyanah, 2017, p. 13). Posters for Ayat-Ayat Cinta 2 (Verses of Love 2, 2017), Surau dan Silek (Prayer Room and Martial Arts, 2017), Cahaya Cinta Pesantren (Loving Light of the Islamic Boarding School, 2017), Ketika Cinta Bertasbih (When Love Prays, 2009), and Bid'ah Cinta (Deviant Love, 2017) depict diverse styles of headscarves, including a face-concealing niqab, an elasticized headscarf for children, two styles of jilbab, and a loosely hanging kerudung that exposes the hair (Figure 8). Generally, however, the headscarves worn by women in film advertisements are those that expose the face but conceal the hair, as common in contemporary Indonesian society.

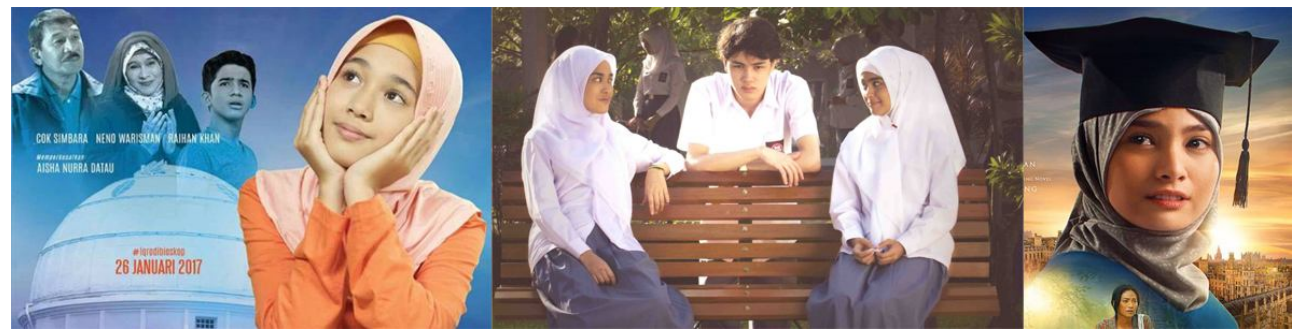

Figure 9. Veiled women in educational pursuits in Iqro (2017), Hijabers in Love (2014), and MARS (2017)

Interestingly, however, film advertisements in the Reform era have shifted away from the frequent depiction of women wearing headscarves as invoking the act of worship. Indeed, in several film advertisements women wearing headscarves are depicted as pursuing higher education or otherwise aspiring to pursuits that have long been male dominated (Figure 9). In the poster for Iqro (2017), for example, a young girl wearing a headscarf is depicted as looking up at the stars, an observatory behind her implying that she seeks to become an astronomer. Meanwhile, posters for the films Hijabers in Love (2014) and MARS (2017) respectively depict women wearing headscarves as seeking an education in a state-run senior high school (implied by the uniform) and at Oxford University. This shift implies a rejection of women being positioned solely as keepers of tradition, positioning them instead as being able to pursue higher education and (implicitly) contribute actively in the public sphere. 
Non-fashion markers of religion are also present in film advertisements from this period. As noted by Imanda (2012, pp. 90-91) in his discussion of film Islami, many of the films advertised use titles that stem from religious terminology. These include a series of films adapted from works by Habiburrahman El Shirazy, which include in their titles the words ayat (verse), tasbih (prayer beads), and mihrab (prayer niche), as well as references to the asma'ul husna (99 names of God) in 99 Cahaya di Langit Eropa (99 Lights in the European Sky, 2013), the Islamic oath of faith in Syahadat

Page 68 Cinta (Oath of Love, 2009), and the common greeting in Assalamualaikum Beijing (Peace on You, Beijing, 2014). However, unlike in the Suharto era, these Arabic-language loan words are not presented in an Arabic script, instead following the standard Indonesian-language transliteration. Indeed, for the most part this script is not present in film advertisements.

For the most part, physical symbols of Islam — aside from the fashion markers discussed aboveare rare in Reform-era film advertisements. Depictions of the Qur'an, of prayer beads, or even of the act of worship itself are limited-even in advertisements for films that present these symbols linguistically through their titles. Only two examples have been identified in the film advertisements reviewed. In the poster for Sajadah Ka'bah (Prayer Rug and Kaaba, 2011), a prayer rug is depicted as a barrier between two rows of people. This is only the prayer rug as a physical object; it is not being used for worship. Meanwhile, in the poster for Mencari Hilal (The Crescent Moon, 2015), an older man is depicted as wearing a skullcap, a Qur'an in his left hand and prayer beads in his right hand (Figure 10). Unlike in the majority of contemporary film advertisements, he is depicted as having been in the act of uttering remembrances (zikir), albeit interrupted by the activities of the young man by his side.

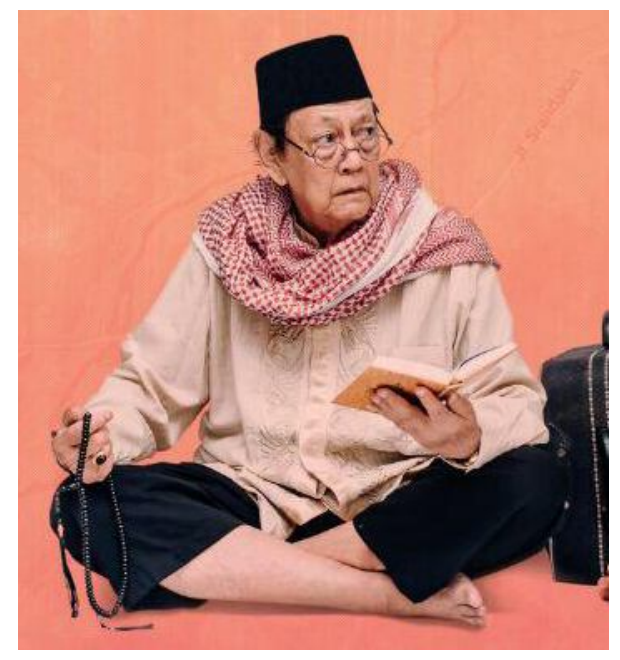

Figure 10. A man with prayer beads and a Qur'an in Mencari Hilal (2015)

Only mosques have remained common in representations of Islam in Reform-era film advertisements. Indeed, these are found in a wide range of advertisements-particularly for films with explicitly Islamic themes-with examples from 99 Cahaya di Langit Eropa (2012), Sang Kiai (2013), and Surau dan Silek (2017) presented in Figure 11 below. Unlike fashion markers, representations of these mosques and other places of worship have remained diverse, with architectural styles reflecting their individual societies. Indeed, unlike during the Suharto era, film advertisements have depicted mosques from traditions outside those of Indonesia and Saudi Arabia, including Byzantine Hagia Sophia in 99 Cahaya di Langit Eropa and the Chinese Niujie Mosque in Assalamualaikum Beijing. Meanwhile, the Kaaba and Masjid Al-Haram have continued to be depicted, as in advertisements for such films as Di Bawah Lindungan Ka'bah (Under the Protection of Kaaba, 2011) and Haji Backpacker (The Backpacker Pilgrim, 2014). 


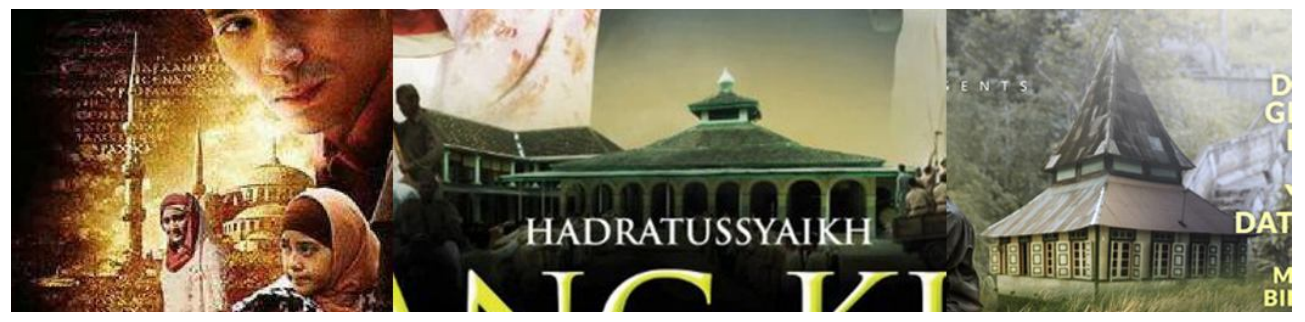

Figure 11. Depictions of the Hagia Sophia in 99 Cahaya di Langit Eropa (2012), a mosque in Sang Kiai (2013), and a surau in Surau dan Silek (2017)

\section{Shifts in the representation of Islam in film advertisements}

In examining the representations of Islam in Indonesian film advertisements from the 1970s through the 2010s, two key shifts are apparent: the positioning of Islam vis-à-vis other religions and ideologies, and the increased homogenization of the religion. These are discussed herein.

In the positioning of Islam relative to Indonesia's other five recognized religions (Protestantism, Catholicism, Hinduism, Buddhism, and Confucianism), as well as relative to other ideologies, there has been a considerable shift. As mentioned above, film advertisements produced under the New Order government were careful to embrace audiences of all religious backgrounds. Some advertisements sought testimonials from non-Muslim viewers who were respected in their fields, as in the quotations offered above. Others positioned these films using more universal appeals; one advertisement for Al-Kautsar, for example, cited a religious scholar named Kyai Haji Misbach as saying that persons of all religions should see the film for its depiction of the struggle between morality and immorality.

This, and other similar practices, was certainly influenced by the socio-cultural context of the time. ${ }^{8}$ Nonetheless, it indicates an attempt to embrace non-Muslim viewers, or Muslim viewers did not share the same ideology as presented by the films. Such a tendency, however, is less evident in advertisements released in the Reform era. Advertisements for films marketed as Islamic no longer bear testimonials from non-Muslims, or from individuals who present them as conveying universal values. Characters likewise tend not present attributes of non-Islamic religions; for example, the poster for 3 Hati Dua Dunia Satu Cinta (3 Hearts Two Worlds One Heart, 2011), a film on interfaith relationships, does not show her wearing a cross necklace despite it being present in the film (Figure 12). This reflects a general tendency in Indonesian film advertisements, where symbols of nonIslamic religions have become uncommon. Where present, such symbols have often been in advertisements for films explicitly promoting interfaith harmony, such as ? (2011).

The Suharto government prohibited activities that could increase tensions between different ethnic groups (suku), religions (agama), races (ras), and/or social groups/classes (antar-golongan), expressed through the initialism SARA. Likewise, the Indonesian Production Codes passed in 1981 required all films to express 'the harmonious coexistence of religions' and 'mutual respect for the practice of faith' (Sen \& Hill, 2007, p. 142). Even before this film code was passed, it is apparent that inclusivity was expected in material intended for public, popular consumption, as seen in advertisements for $A l$ Kautsar (1977). 


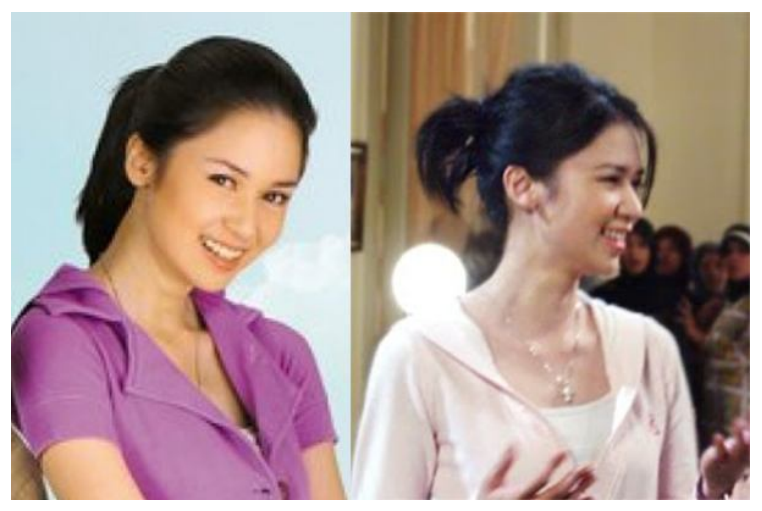

Figure 12. Della in the poster for 3 Hati Dua Dunia Satu Cinta (2010) and in the film
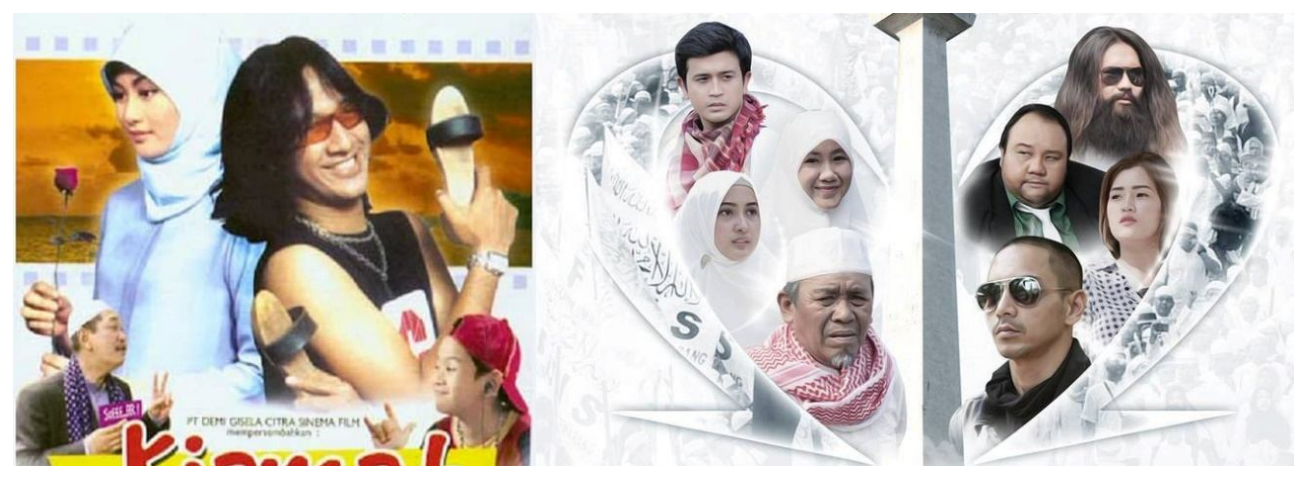

Figure 13. Opposition of Islamic and non-Islamic attributes in Kiamat Sudah Dekat (2003) and 212: The Power of Love (2018)

Representations of the relationships between specific understandings of Islam and other understandings (or even other ideologies) have been somewhat more diverse. Perhaps most striking are the posters for Kiamat Sudah Dekat (The End is Nigh, 2003) and 212: The Power of Love (2018), seen in Figure 13. Both advertisements position characters with Islamic fashion markers as diametrically opposed to persons who seemingly embrace other systems of belief. In the former, a calm veiled woman, implicitly linked to the metaphor of womanhood as a flower through her rose, is placed opposite a rocker wearing chains and sunglasses; below them, a man in a skullcap is diametrically opposed a youth in a baseball cap whose hands form the 'sign of the horns' common in heavy metal culture. Meanwhile, in the latter, a set of four well-kempt Muslims in white attire, headscarves, and skullcaps are set opposite individuals whose fashion markers suggest them to be, respectively, a person of poor personal grooming, a business executive, a Chinese woman, and a thug (preman). The distance between them is underscored by the central pillar of the National Monument in Jakarta, a visual barrier between them.

In other advertisements, tension is still present, yet not presented as starkly. The poster for Surga yang Tak Dirindukan (An Unwanted Paradise, 2015), for example, depicts a veiled woman in a pink jacket, standing next to a young man and smiling. Behind them, in the distance, is an unveiled woman in a tight shirt and jeans, seemingly upset at their happiness. This contrast indicates a degree of tension between them, which is expanded upon in the film. ${ }^{9}$ This tension is resolved in advertisements for the film's 2017 sequel Surga yang Tak Dirindukan 2, in which both female characters wear white headscarves, tied in the same fashion (Figure 14). This transformation, from veiled to unveiled, suggests a tendency towards viewing homogenization as a means of preventing conflict. Such

9 In the Surga yang Tak Dirindukan, the character Mei Rose is presented as becoming pregnant out of wedlock and as 'stealing' a woman's husband, ultimately becoming his second wife. There is a tendency in Indonesian films for the women who commit extramarital affairs and become pregnant outside of wedlock to be presented as not wearing headscarves; a similar case is found in Assalamualaikum Beijing (2014), although the advertisements for that film do not depict the character in question. 
homogenization is also apparent in advertisements for Ketika Cinta Bertasbih (When Love Prays) and its sequel, both released in 2009.

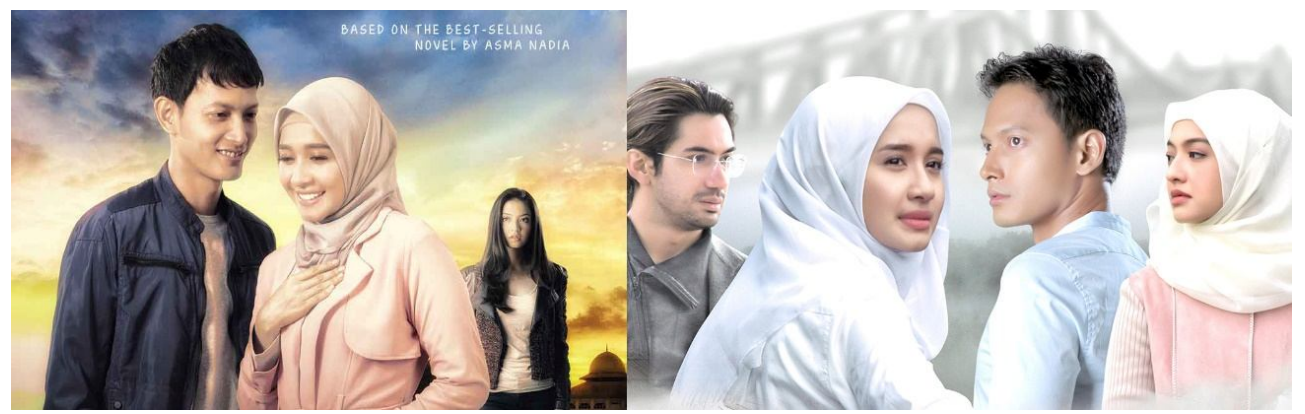

Figure 14. The veiling of Mei Rose between Surga yang Tak Dirindukan (2015) and Surga yang Tak Dirindukan 2 (2017)

Other film advertisements have been more inclusive in positioning films' understandings of Islam relative to other understandings and ideologies. Some advertisements, such as those for Catatan Akhir Kuliah (Notes from the End of University, 2015) and Hijab (2015), for example, depict women (and, in the former, men) wearing a wide range of fashion markers interacting as equals (Figure 15). The former depicts young women in headscarves, interacting in a university setting with women who are not veiled, including one with exposed shoulders and another in business attire. In the latter, meanwhile, four women are depicted standing on a stage together, smiling. The clothing of each woman is indicative of a different understanding of the requirement to cover one's private areas, or aurat (and, by extension, a different understanding of Islam). Although tension is suggested by their presentation as mannequins, this tension is not between the women themselves, but rather between them and the persons holding the strings.

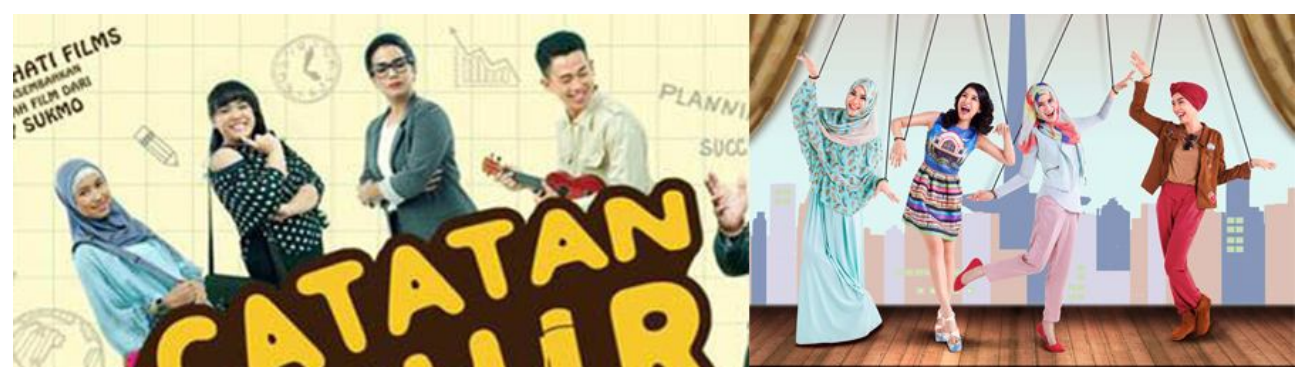

Figure 15. Depictions of differing fashion markers in Catatan Akhir Kuliah (2015) and Hijab (2015)

\section{CONCLUSION}

This article has examined the representation of Islam in Indonesian film advertisements, drawing on a corpus of 600 flyers and posters for films released between 1968 and 2018. Building on a previous study that focused solely on the Suharto era (Woodrich, 2017), it has shown that, during the Suharto era, film advertisements used diverse markers such as turbans, skullcaps, headscarves, language, the Qur'an, prayers, prayer beads, mosques, and the Kaaba to project an Indonesian Islamic identity. This identity was shown, through commentary from (explicitly identified) non-Muslims and emphasis of universal values, to be non-exclusive, even as religious themes only being emphasized in films that prominently featured Islam suggests the religion received positioning in contemporary Indonesian popular discourse. Meanwhile, Islam was positioned as having diverse practices, but ultimately uniting all Muslims in a shared faith.

Meanwhile, during the Reform era, film advertisements have used somewhat less diverse markers. Fashion markers such as turbans, skullcaps, and headscarves, as well as markers such as 
language and mosques, remain important in representing an Indonesian Islamic identity, while the Qur'an, worship, and prayer beads are only rarely depicted. In the Reform era, understandings of Muslim masculinities and the position of women have shifted, with men becoming more urbane and women being more commonly depicted in the public sphere. However, at the same time, there has been a tendency_especially in advertisements for films classified as film Islami-towards increased homogenization in the representation of specific Muslim. In some cases, specific Islamic identities

Page 72 have even been placed in direct opposition to other identities.

This discussion indicates that, as Islam has enjoyed continued-or even strengthenedspecial positioning in Indonesian discourse, there has been a trend in Indonesian film advertising towards representing it as more exclusive. Even when diverse ideologies and understandings of Islam are implied in advertisements, this does not extend to religious minorities as it did (to some extent) under the Suharto government. Nonetheless, while some film advertisements have ignored or even marginalized individuals who do not meet the 'authentic Islamic ideals' (Lücking \& Eliyanah, 2017, p. 13) to which they aspire, others have sought to include some diversity in their depictions of Indonesian life. This indicates that film advertisements, as with the films they advertise, are sites of discourse on issues of Indonesian religious identity and the role of religion in everyday life.

\section{BIBLIOGRAPHY}

\section{Advertisements}

360 Degrees Synergy, Nant Entertainment, and Josh Pictures. (2017). Galih dan Ratna.

Andalan Sinema \& iSee Production. (2014). Hijabers in love.

Citra Indah Film \& Madu Segara Film. (1974). Karmila.

Darihati Films. (2015). Catatan akhir kuliah.

Demi Gisela Citra Sinema. (2003). Kiamat sudah dekat.

Dipa Jaya Film. (1981). Si Pitung beraksi kembali.

Falcon Pictures \& Rumah Kreatif 23. (2011). Sajadah Ka'bah.

Falcon Pictures. (2014). Haji backpacker.

Falcon Pictures. (2015). Negeri van Oranje.

Firman Abadi Film. (1986). Menggapai matahari II.

Fullframe Pictures. (2017). Cahaya cinta pesantren.

Garuda Film, Interstudio, \& Dharma Putra Jaya Film. (1980). Usia 18.

Gemini Satria Film. (1979). Anak-anak buangan.

Haka Film. (1979). Kutukan Nyai Roro Kidul.

Hanna Internasional Film. (1978). Begadang.

Kamasutra Film. (1977). Jakarta, Jakarta.

Kaninga Pictures. (2017). Bid'ah cinta.

Legacy Pictures and Screenplay Films. (2017). Kartini.

Mahakarya Pictures \& Malin Films. (2017). Surau dan silek.

Mahaka Pictures \& Dapur Film Production. (2011). ?.

Masjid Salman ITB \& Salman Film Academy. (2017). Iqro: Petualangan meraih bintang.

Matari Artis Jaya Film. (1980). Permainan bulan Desember.

Maxima Pictures. (2013). 99 cahaya di langit Eropa.

Maxima Pictures. (2014). Assalamualaikum Beijing.

Maxima Pictures. (2015). LDR.

MD Pictures. (2008). Ayat-ayat cinta.

MD Pictures. (2011). Di Bawah lindungan Ka'bah.

MD Pictures. (2015). Surga yang tak dirindukan.

MD Pictures. (2017a). Ayat-ayat cinta 2.

MD Pictures. (2017b). Surga yang tak dirindukan 2.

Mitra Djaya Film \& Putra Utama Film. (1977). Panggilan Ka'bah.

Mizan Productions. (2011). 3 hati dua dunia satu cinta.

Multi Buana Kreasindo et al. (2016). MARS.

Multivision Plus Pictures. (2010). Sang pencerah.

MVP Pictures et al. (2015). Mencari hilal.

Naviri Film. (1979a). Cinta segi tiga. 
Naviri Film. (1979b). Cinta segi tiga.

Piramid Citra Perkasa. (2008). Syahadat cinta.

Putra Utama Film. (1978). Ya Allah ampuni dosaku.

Rapi Film. (1980). Aladin dan lampu wasiat.

Rapi Film. (1982). Pasukan berani mati

Rapi Films. (2013). Sang kiai.

Rhoma Irama Film. (1983). Satria bergitar.

Sippang Jaya Film. (1977a). Al-Kautsar.

Sippang Jaya Film. (1977b). Al-Kautsar.

SinemArt Pictures. (2004). Brownies.

SinemArt Pictures. (2009a). Ketika cinta bertasbih.

SinemArt Pictures. (2009b). Ketika cinta bertasbih 2.

SinemArt Pictures. (2010). Dalam mihrab cinta.

Siregar, Shalahuddin. (2011). Negeri di bawah kabut.

Soraya Intercine Film. (1984a). Permainan tabu.

Soraya Intercine Film. (1984b). Telaga angker.

Taty \& Sons Jaya Film. (1977). Para perintis kemerdekaan.

Tim Dapur Film, Ampuh Entertainment, \& MVP Pictures. (2015). Hijab.

Tobali Indah Film \& Empat Gajah Film. (1985). Sunan Kalijaga dan Syech Siti Jenar.

Tobali Indah Film. (1983). Sunan Kalijaga.

Warna Pictures. (2018). 212: The Power of Love.

Other References

Crossette, B. (1985), 3 February. Suharto and Islam clash on principle. The New York Times. Downloaded from http://www.nytimes.com/1985/02/03/weekinreview/suharto-and-islamclash-on-principle.html on 11 November 2016.

Hasan, N. (2011). Political Islam in Indonesia. In I. Ahmed (ed.). The politics of religion in South and Southeast Asia. New York: Routledge.

Hasyim, S. (2006). Understanding women in Islam: An Indonesian perspective. Jakarta: Solstice.

Hefner, R. (1999). Islam and nation in the Post-Suharto Era. I A. Schwarz and J. Paris (eds.). The politics of Post-Suharto Indonesia. New York: Council on Foreign Relations Press.

Herlina, D., et al. (2017). Siapa dan bagaimana penonton bioskop hari ini: Jakarta, Bandung, Surabaya. Paper presented at the First Indonesian Cinema Conference, Universitas Muhammadiyah Yogyakarta, 29-31 August.

Imanda, T. (2012). Independent versus mainstream Islamic cinema in Indonesia: Religion using the market or vice versa?. In T. Baumgärtel (ed.), Southeast Asian independent cinema: Essays, documents, interviews. Hong Kong: Hong Kong University Press. pp. 89-104.

Intan, B.F. (2006). 'Public religion' and the Pancasila-based state of Indonesia: An ethical and sociological analysis. New York: Peter Lang.

Kristanto, J.B. (ed.). (2007). Katalog film Indonesia 1926-2007. Jakarta: Nalar.

Lücking, M., \& Eliyanah, E. (2017). Images of authentic Muslim selves: Gendered moralities and constructions of Arab others in contemporary Indonesia, Social Sciences 6(3).

Melton, J.G. (2014). Faiths across time: 5,000 years of religious history. Vol. 4. Santa Barbara: ABCCLIO.

Ramage, D. (1995). Politics in Indonesia: Democracy, Islam, and the ideology of tolerance. New York: Routledge.

Ricklefs, M. (2008). A history of modern Indonesia since c. 1200. $4^{\text {th }}$ Edition. New York: Palgrave Macmillan.

Salam, A. (2004). Oposisi sastra Sufi. Yogyakarta: LKiS.

Sen, K. and Hill, D.T. (2007). Media, culture and politics in Indonesia. Jakarta: Equinox Publishing.

Van Wichelen, S. (2009). Formations of public piety: New veiling, the body, and the citizen-subject in contemporary Indonesia. In B.S. Turner \& Y. Zheng (eds.). The body in Asia. New York: Berghahn Books.

Vatikiotis, M. (1998). Indonesian politics under Suharto: The rise and fall of the New Order. London, New York: Routledge.

Woodrich, C.A. (2015). A Lacanian psychoanalysis of the character Karman in Ahmad Tohari's Kubah. Lingua Idea. 6(2). pp. 18-35. 
Woodrich, C.A. 2017. Perkembangan Islam dan praktek Islam dalam selebaran film Indonesia di era Soeharto (1966-1998). Wardah. 18(1). pp. 13-33.

\section{Page $\mid 74$}

